\title{
Red deer bone and antler collagen are not isotopically equivalent in carbon and nitrogen \\ Rhiannon E. Stevens ${ }^{1 *}$ and Tamsin C. O’Connell ${ }^{1,2}$
}

To be submitted to Rapid Communications in Mass Spectrometry

${ }^{1}$ McDonald Institute for Archaeological Research, University of Cambridge, Downing Street, Cambridge, CB2 3ER, UK.

${ }^{2}$ Department of Archaeology \& Anthropology, University of Cambridge, Downing Street, Cambridge, CB2 3DZ, United Kingdom.

* New contact details for corresponding author: Institute of Archaeology, University College London, 31-34 Gordon Square, London, WC1H OPY, UK

Corresponding author: Rhiannon Stevens: rhiannon.stevens@ucl.ac.uk

\section{RATIONALE}

Bone and antler collagen $\delta^{13} \mathrm{C}$ and $\delta^{15} \mathrm{~N}$ values are often assumed to be equivalent when measured in palaeodietary, palaeoclimate and palaeocological studies. Although compositionally similar, bone grows slowly and is remodelled whereas antler growth is rapid and remodelling does not occur. These different patterns of growth could result in isotopic difference within antler and between the two tissue types. Here we test whether red deer (Cervus elaphus) bone and antler $\delta^{13} \mathrm{C}$ and $\delta^{15} \mathrm{~N}$ values are isotopically equivalent, and whether intra-antler isotopic values are uniform.

\section{METHODS}

Bone and antler were isotopically analysed from 6 stags that lived in a temperate maritime climate on Isle of Rum, Scotland. Multiple antlers from different years were sampled per individual, together with a single bone sample per individual. Up to 12 samples were taken along the length of each antler (total of 25 antlers, 259 samples) so that a chronological record of the isotopic composition during antler growth could be obtained. Collagen was extracted and its $\delta^{13} \mathrm{C}$ and $\delta^{15} \mathrm{~N}$ values were measured by continuous-flow isotope ratio mass spectrometry.

\section{RESULTS}

Intra-antler collagen isotope signatures vary, and show that not all antler from an individual or a growth year are equivalent in carbon and nitrogen isotopic values. $\delta^{15} \mathrm{~N}$ values typically increases with distance along antler length, but no overall trend is observed in $\delta^{13} \mathrm{C}$ values. An isotopic offset is visible between bone and antler, with bone $\delta^{13} \mathrm{C}$ and $\delta^{15} \mathrm{~N}$ values being higher in most cases.

\section{CONCLUSIONS}

Bone and antler collagen $\delta^{13} \mathrm{C}$ and $\delta^{15} \mathrm{~N}$ values are not isotopically equivalent and are therefore not directly comparable in palaeodietary, palaeoclimate and palaeocological studies. Bone and antler collagen isotopic differences likely relate to differential 
metabolic processes during the formation of the two tissues. Intra and inter-antler isotopic variations likely reflect the isotopic composition of an individual's diet rather than physiological parameters, and may have potential to provide high-resolution individual-specific information in modern and ancient cervid populations.

Keywords stable isotope, sequential sampling, climate, palaeodiet, turnover

\section{Introduction}

Throughout prehistory cervids have had a special relationship with humans, as prey for Palaeolithic hunter-gathers throughout Eurasia ${ }^{[1]}$, as a source of material for use as tools such as Neolithic antler picks found at Durrington Walls ${ }^{[2]}$, or as an expression of wealth as seen at Medieval deer parks ${ }^{[3]}$. Deer are native to most regions of the globe, with Antarctica, Australia, central and southern Africa, Madagascar and New Zealand being the exceptions ${ }^{[4]}$. The flexible behaviour displayed by many deer species has allowed deer to adapt to virtually every ecological context, from dry deserts to woodlands, prairies, marshes and Arctic regions ${ }^{[4]}$. Thus cervid skeletal remains are found at archaeological and palaeontological sites from many time periods across large regions of the world.

Carbon and nitrogen isotope signatures of bone and antler are now often used to reconstruct the ecological conditions in which ancient deer lived, to track past habitat changes in the vicinity of the sites of recovery, and to infer past human management practices $^{[5,6,7,8,9,10,11,12,13,14,15,16,17,18,19]}$. They are also used to define isotopic baselines to which human isotope signatures can be compared ${ }^{[20,21]}$. This is possible as herbivore proteinaceous body tissues predominantly reflect the isotopic composition of the plants (primarily that of the protein) consumed by the herbivore, potentially modulated by physiology and diet composition ${ }^{[22,23,24,25,26,27,28,29,30,31]}$, and there is isotopic variation in plants within and between ecosystems in both space and time due to physiological and environmental / climatic parameters ${ }^{[32,33,34,35,36,37,38,39,40]}$.

Researchers often consider antler and bone $\delta^{13} \mathrm{C}$ and $\delta^{15} \mathrm{~N}$ values collectively ${ }^{[5,14,18]}$, however at present the question of whether bone and antler isotope signatures are equivalent and directly comparable has not yet been thoroughly addressed. A large body of research shows that individuals of all species yet studied are not isotopically homogeneous, with different body tissue having different isotopic values within individuals on constant diets depending of turnover rate and tissue composition $^{[24,41,42,43,44,45,46,47]}$. Whilst bone and antler are compositionally similar, both being a composite of protein (mostly collagen) and hydroxyapatite mineral, they grow in different ways. Antlers grow very rapidly over a period of a few months typically during the spring to summer period. They do not remodel and are shed annually, so their isotopic composition is likely to reflect the body's isotopic pool over a short time period (months), which should reflect seasonal variations in diet (both in terms of its plant species composition and plant isotopic signatures), seasonal variation in deer behaviour, and ontogenetic variation in metabolism. This could potentially result in isotopic variations along the length of an individual's antler. By contrast bone grows relatively slowly and continues to remodel throughout life, thus its isotope composition is likely to reflect a long-term average of the body's isotopic pool. In this study we investigate whether bone and antler collagen carbon and nitrogen isotopic values from 
individual deer are similar, by measuring the isotope signatures of bone and antler collagen from six male red deer.

\section{Bone and antler structure and composition}

Bone is primarily composed of the protein collagen and the mineral calcium hydroxyapatite ${ }^{[48]}$. Two processes are involved in mammal bone growth; endochondral and intramembranous ossification. Once formed, bone structure does not remain static, as it remodels throughout life ${ }^{[49]}$. Bone tissue is removed by osteoclasts, and then new bone is formed by osteoblasts. Thus the isotopic composition of bone reflects the individual's diet over a considerable period of time, typically the last few years of life and potentially longer than 10 years in long-lived mammals ${ }^{[49,50,51]}$.

Antlers are also composed of collagen and calcium hydroxyapatite and grow from pedicles on the frontal bones of deer skulls. Only the males of most species of the deer family (Cervidae) grow antlers, with reindeer (Rangifer) being the exception, as both males and females develop antler ${ }^{[52]}$. Antlers grow in a variety of shapes (branched and un-branched) and sizes, from a few centimetres (e.g. Pudu; Pudu puda) up to 1.5 metres (e.g. Wapiti; Cervus canadenesis) ${ }^{[4,52]}$, usually over a period of several months. Antler growth occurs by a process of modified endochondral ossification at the distal tip of each branch. A tubular framework is developed, initially composed of mineralized cartilage, which is later converted to a framework composed of micro-lamellar bone. The tubular framework is then in filled by primary osteons, which consist of bone with collagen fibrils. An antler barely grows radially once it starts to grow in length ${ }^{[52]}$. In red deer, antlers typically grow to around $80 \mathrm{~cm}$ in length, with as much as $6-7 \mathrm{~mm} /$ day of growth ${ }^{[52,53]}$. Antlers start growing immediately after the previous year's antlers are cast $^{[4]}$. The growth rate is not constant, typically following an S-shaped curve: the first 30 to 45 days of growth are relatively slow, followed by 60 to 80 days of rapid exponential growth which then slows as autumn approaches ${ }^{[54]}$. Once growth is complete, the velvet skin covering the hard antler bone is shed, by which time the antlers are fully-grown and mineralized ${ }^{[4]}$. The deer typically keep their fully-grown exposed antlers through the autumn and winter until the following spring, when they are cast and the antler growth cycle recommences.

\section{EXPERIMENTAL}

\section{Sample selection}

Antler and bone were sampled from the Isle of Rum, Scotland $\left(5701^{0} \mathrm{~N}, 0617^{0} \mathrm{~W}\right.$, NM-402996). Red deer (Cervus elaphus) living in the North block study area of the Isle of Rum, which is approximately $12 \mathrm{~km}^{2}$ ( $\mathrm{see}^{[55]}$ Figure 1), have been part of an individual-based study for over 30 years. The study area consists of areas of highquality, herb-rich Agrostis-Festuca grassland (where deer population density is highest) and poorer quality Calluna, Trichoforum, Molina heath, and Molinia grasslands ${ }^{[56]}$. Individual deer are recognizable as a result of artificial markings applied when calves are captured at birth, and natural marks. Censuses of the North Block study area have been carried out since 1974, with at least five per month for eight months of the year, and more intensive observations during the calving and rutting seasons. During censuses, observers follow a set route and record the identities, locations (to the nearest $100 \mathrm{~m}^{2}$ ordinance survey grid square) of all deer observed ${ }^{[55,57]}$. Cast antlers are collected and are attributable to an individual, since each stag grows antlers that are unique in their morphology and size, recorded via regular observations throughout the 
year. When deer die, the skull of each individual is collected, defleshed through dissection, and stored.

Bone and antler samples for this study were taken from 6 stags that were born between 1985 and 1990, died natural deaths between 1999 and 2004, and at death were between 9 and 14 years old (Table 1). From each individual, several antler were available for analysis, whereas only a single bone sample was available: this is an inevitable outcome of comparing a tissue that is annually shed to one that must be sampled post-mortem for this population.

Bone samples were taken from the mandible, which was the only bone available for sampling (a total of 6). Multiple antlers were sampled per individual, collected in different years, including the antler formed in the year prior to death. For each antler multiple samples were taken down the length (up to 12 samples per antler) so that a chronological record of the isotopic composition during growth could be obtained. In total 25 antlers were sampled for isotopic analysis. For four individuals, antlers from five different years were sampled, for one individual, antlers from four years were sampled, and for one individual a single antler was sampled. Census data show that for each individual, the previous year's antlers were cast between the end of March and mid April, and the velvet was cleaned from the new year's antler growth by early to mid August. Thus the antlers sampled for this study took 3.5 to 4.5 months to grow (Table 1). For each antler a sample was taken at the coronet (formed first), then $5 \mathrm{~cm}$ from the coronet, then every $7.5 \mathrm{~cm}$ down the main beam of the antler, and at the tip of the antler (formed last)(Figure 2). In addition, for 2 antlers, samples were taken along the brow, trey and top point branches; the first sample was taken at the branch junction, and then samples were taken every $5 \mathrm{~cm}$ along each branch.

\section{Stable isotope analysis}

A total of 259 antler and 6 bone samples were collected and prepared for collagen carbon and nitrogen isotope analysis. The surface of the bone or antler was cleaned with a tungsten drill bit. A hole was then drilled into the bone or antler and the powder produced was collected for analysis. Samples were prepared according to a modified Longin method ${ }^{[58]}$, in a manner similar to that described by O'Connell et al. ${ }^{[59]}$. Around $300 \mathrm{mg}$ of bone / antler powder was defatted by soaking in $8 \mathrm{ml}$ methanol and chloroform $(2: 1 \mathrm{v} / \mathrm{v})$ for $3 \mathrm{~h}$ whilst in an ultrasonic bath. The solvent was changed at least 5 times with the samples being centrifuged for 5 mins prior to changing the solvent to facilitate the process. The soaking, ultrasonicating, and centrifuging process was repeated three times with distilled water. Samples were demineralised in $0.5 \mathrm{M}$ aq. hydrochloric acid at $4^{\circ} \mathrm{C}$ until complete decalcification and then rinsed with distilled water and centrifuged three times for 5 minutes between washes. Samples were then gelatinised by heating in $\mathrm{pH} 3.0$ aqueous hydrochloric acid at $75^{\circ} \mathrm{C}$ for 48 hours. The liquid fraction containing the dissolved collagen was filtered off using a 60-90 $\mu \mathrm{m}$ Ezee filter (Elkay, UK), frozen overnight at $-20^{\circ} \mathrm{C}$, then stored at $-80^{\circ} \mathrm{C}$ for 4 hours and finally lyophilised. The lyophilised collagen was weighed into tin capsules for isotope analysis. Samples were analysed in triplicate using an automated elemental analyser (Costech Analytical, Valencia, CA, USA) coupled in continuous-flow mode to a Thermo Finnigan MAT253 mass spectrometer (Thermo Fisher Scientific, Bremen, Germany) at the Godwin Laboratory, Department of Earth Sciences, University of Cambridge. Carbon and nitrogen results are reported using the delta scale in units of 'permil' (\%o) relative to internationally accepted standards VPDB and AIR respectively ${ }^{[60]}$. Based on replicate analyses of international (IAEA: caffeine and 
glutamic acid-USGS-40) and in-house laboratory standards (nylon, alanine and bovine liver standard) precision is better than $\pm 0.2 \%$ o for both $\delta^{13} \mathrm{C}$ and $\delta^{15} \mathrm{~N}$ values.

\section{RESULTS AND DISCUSSION}

Collagen was successfully extracted from all samples. The atomic $\mathrm{C} / \mathrm{N}$ ratios for the bone collagen samples ranged between and 3.1 and 3.2, and for the antler collagen samples ranged between 3.1 and 3.3, which is close to the calculated atomic $\mathrm{C} / \mathrm{N}$ ratio of collagen, and indicates no extraneous carbon contamination from lipids. (See online supplementary dataset for full list of atomic $\mathrm{C}: \mathrm{N}$ ratios). Both the carbon and nitrogen isotope data are normally distributed.

Due to the "fossil fuel effect", the carbon isotopic values of bones and antler collected in different years are not directly comparable. The burning of fossil fuel has reduced atmospheric $\delta^{13} \mathrm{C}$ values, and continues to so $\mathrm{do}^{[61,62]}$, with the effect in turn being passed on to plant and animals. To control for this "fossil fuel effect" the deer bone and antler $\delta^{13} \mathrm{C}$ values were corrected following the formula given by Long et al. ${ }^{[63]}$. This formula calculates the change in atmospheric $\mathrm{CO}_{2} \delta^{13} \mathrm{C}$ between 1880 (based on modeled high-precision records of atmospheric $\mathrm{CO}_{2}$ from Antarctic ice) and the year in which a tissue sample was obtained, then and adds this value to collagen $\delta^{13} \mathrm{C}$ values. For the antler we corrected values based on the year of antler growth $\left(\delta^{13} \mathrm{C}_{\text {corr-ant }}\right)$ (i.e. Year prior to casting/collection). For bone, we used two corrections based on the individual's year of death $\left(\delta^{13} \mathrm{C}_{\text {corr-death }}\right)$ and the average of last five years of life $\left(\delta^{13} \mathrm{C}_{\text {corr-5yr }}\right)$. Bone turns over in a non-systematic way, and the carbon isotopic value of the mandible bone sample collected represents an integrated signal spanning the duration of bone formation and turnover. Most likely neither of these corrections are completely accurate but are likely to bracket the true value (see later discussion). Bone and antler measured and corrected $\delta^{13} \mathrm{C}$ values and measured $\delta^{15} \mathrm{~N}$ values are given in the online supplementary data set. All further discussion of carbon isotopic data refers to corrected $\delta^{13} \mathrm{C}$ values.

The bone isotopic values $(\mathrm{n}=6)$ are tightly clustered, with $\delta^{13} \mathrm{C}_{\text {corr-death values ranging }}$ from $-21.0 \%$ o to $-20.1 \%$ ( mean $=-20.8 \pm 0.4 \%$ ),$\delta^{13} \mathrm{C}_{\text {corr-5yr }}$ values ranging from $-21.1 \%$ o to $-20.2 \%$ o (mean $=-20.9 \pm 0.4 \%$ ) and $\delta^{15} \mathrm{~N}$ values from $4.2 \%$ o to $5 \%$ o (mean $=4.6 \%$ o $\pm 0.3 \%$ o) (Table 2). There is little difference between the two corrected bone carbon isotopic values for each individual. The antler carbon and nitrogen isotopic values (all individuals, all years, $\mathrm{n}=259$ ) have a broader spread, with $\delta^{13} \mathrm{C}_{\text {corr-ant }}$ values from $22.1 \%$ o to $-20.7 \%$ (mean $=-21.4 \pm 0.3 \%$ ) and $\delta^{15} \mathrm{~N}$ values from $3.4 \%$ o to $4.9 \%$ (mean $=$ $4.2 \pm 0.3 \%$ ) (Table 2 for summary, Table 3 for each antler, Figure 3 ).

Intra- and inter- year variation in antler isotopic values:

Analysis of multiple antlers grown in the same year show that in one year different individuals can have very different antler isotopic values, and this pattern of variation can be different in carbon and nitrogen (Figures 4 and 5, and online supplementary data set). In some years, all antlers analysed are very similar both in terms of the pattern of isotopic variation and their isotopic values (e.g. 1998 for $\delta^{13} \mathrm{C}_{\text {corr-ant }}$ ). In other years, there is substantial variation between the antlers analysed (e.g. 1999 for $\delta^{15} \mathrm{~N}$ ). The intra-year range (for years where 3 or more antlers were available) was $0.5 \%$ o to $1 \%$ o

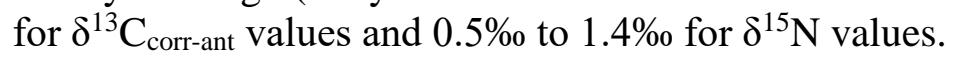


Analysis of multiple antlers grown in different years by the same individuals shows that for some individuals there is limited difference in the isotope signatures (mean, max, min or range in $\delta^{13} \mathrm{C}_{\text {corr-ant }}$ and $\delta^{15} \mathrm{~N}$ values) between years (e.g. SAF85), whilst for others the difference between years is greater (e.g. TYS 89 for $\delta^{15} \mathrm{~N}$ ) (Figures 6 and 7). The inter-year range for an individual is $0.8 \%$ to $1.4 \%$ o for $\delta^{13} \mathrm{C}_{\text {corr-ant values and } 0.7 \% \text { o }}$ to $1.2 \%$ for $\delta^{15} \mathrm{~N}$ values. There are no correlations between the year of antler growth and mean, max, min or range in $\delta^{13} \mathrm{C}_{\text {corr-ant }}$ and $\delta^{15} \mathrm{~N}$ values (Pearson's correlation coefficient). Although the mean $\delta^{13} \mathrm{C}_{\text {corr-ant }}$ and $\delta^{15} \mathrm{~N}$ values are significantly different between years for some individuals this is not the case for all animals (e.g. SAF85 $\delta^{15} \mathrm{~N}$ ) (one-way ANOVA with post-hoc Bonferroni correction, online supplementary dataset). Furthermore, where significant differences are present, they are not consistently seen between the same years for each individual. This suggests that the factors driving isotopic variation between years are more likely to be at the individual level (e.g. dietary preference) rather than at the group scale (e.g. climatic parameters such as precipitation or temperature influencing the plant isotope composition), although the relatively small sample size hinders a full exploration of environmental drivers of isotopic change.

\section{Intra-individual antler isotopic variation:}

When considering all antler analyses across all years from each stag, we see considerable variation in the range of intra-individual isotopic values (Table 2): within an individual, the ranges span from $0.8 \%$ o to $1.4 \%$ in $\delta^{13} \mathrm{C}_{\text {corr-ant }}$ values, and $0.7 \%$ o to $1.5 \%$ in $\delta^{15} \mathrm{~N}$ values (excluding PIC90 for whom there is only a single antler which has a range of $0.5 \%$ and $0.1 \%$ in $\delta^{13} \mathrm{C}_{\text {corr-ant }}$ and $\delta^{15} \mathrm{~N}$ values respectively). The intra-antler isotopic variation is generally less, ranging from $0.2 \%$ to $0.8 \%$ in $\delta^{13} \mathrm{C}_{\text {corr-ant values and }}$ from $0.1 \%$ to $0.8 \%$ in $\delta^{15} \mathrm{~N}$ values (Table 5). Antler $\delta^{13} \mathrm{C}_{\text {corr-ant }}$ and $\delta^{15} \mathrm{~N}$ values do not co-vary. No correlation was observed between any aspect of the $\delta^{13} \mathrm{C}_{\text {corr-ant }}$ or $\delta^{15} \mathrm{~N}$ signatures and the side of antler (left or right), length of antler, age at which or year in which antler grew, and whether the antler was sampled after casting or after death (i.e. still attached to skull).

The pattern of intra-antler isotopic variation differs between each of the five individuals for whom we have multiple antlers (Figure 6). In SAF85 both the pattern of intra-antler carbon and nitrogen isotopic variation and the absolute isotopic values are broadly similar between years (Figure 7) suggesting the isotopic signature of the diet consumed and the cyclical metabolic changes did not differ greatly between years. For two individuals (SUR86 and FAN85) the pattern of isotopic variation is consistent between years, but the absolute isotopic values differ (Figure 6). By contrast both the pattern of intra-antler $\delta^{15} \mathrm{~N}$ variation and the range of $\delta^{15} \mathrm{~N}$ values for TYS89 differed greatly between years. For INI85, antler from three years have very similar $\delta^{13} \mathrm{C}_{\text {corr-ant }}$ and $\delta^{15} \mathrm{~N}$ values, whereas those from two other (non-sequential) years are very different (1997 seen in the $\delta^{13} \mathrm{C}_{\text {corr-ant }}$ values and 2000 seen in the $\delta^{15} \mathrm{~N}$ values). Whilst our dataset is too small to allow a full exploration of all influencing factors behind the observed intraantler variation, what is obvious is that there is no simple consistent pattern in the yearto-year variation, which suggests that external factors such as environmental changes are not likely to be the dominant drivers.

The intra-antler sampling allows us to examine isotopic change during the growing season (i.e. along the length of the antler and along different branches). Samples were taken along the brow, trey and point branches for two antler from two individuals 
(INI85's 1995 antler and TYS89's 1997 antler). Both the $\delta^{13} \mathrm{C}_{\text {corr-ant }}$ and $\delta^{15} \mathrm{~N}$ values along these branches are similar to those at equivalent points on the main beam (Figure 8 ). This suggests that that as long as the distance of the sample from the coronet can be measured, any of the branches can be chosen for sampling, although the main beam may be preferable as it is the longest.

When examining all antler no consistent change is seen in the pattern of carbon isotopic values within each antler (Figure 6); the mean $\delta^{13} \mathrm{C}_{\text {corr-ant values of the three antler }}$ samples closest to the coronet and the three antler samples furthest from the coronet are not significantly different (Two-tailed Student t-test) (Table 3). That there is no obvious change in antler $\delta^{13} \mathrm{C}$ values over the season of growth suggests that either the dietary resources show no seasonal shift in $\delta^{13} \mathrm{C}$ values ${ }^{[64]}$ or that any shift is not significant enough to register in the body carbon isotopic pool, or alternatively that there are shifts in vegetation $\delta^{13} \mathrm{C}$ values as well as concomitant isotopic shifts due to dietary change or physiology, and that these effectively cancel each other out.

By contrast an upward trend in nitrogen isotopic values is visible within most antlers (Figure 6). In 21 out of the 25 antlers, the mean $\delta^{15} \mathrm{~N}$ of the three antler samples furthest from the coronet is higher than that of the three antler samples closest to the coronet, whereas in three antlers they are the same, and in one, the three antler samples furthest from the coronet have a lower mean $\delta^{15} \mathrm{~N}$ than those closest to the coronet (Table 3 ). This generally consistent $\delta^{15} \mathrm{~N}$ pattern could be due to either all animals changing their diet in a consistent manner during the formation of their antlers, or alternatively that the $\delta^{15} \mathrm{~N}$ composition of the diet they consumed increased during the period of antler growth, or it could be related to physiological cycles. The observed upward trend is not consistent with the pattern we would expect if rapid growth, the likely dominant physiological effect to do with tissue synthesis, was influencing the antler $\delta^{15} \mathrm{~N}$ values. Lack of steady state during rapid growth has been shown to result in lower $\delta^{15} \mathrm{~N}$ values $^{[26,65,66,67,68,69,70]}$. If this were the single controlling parameter we would expect $\delta^{15} \mathrm{~N}$ in slowly laid down antler (at the base and the tip) to be similar and higher than the rapidly laid down antler (in the middle). The positive trend in antler $\delta^{15} \mathrm{~N}$ values may also be linked to a flourishing of nutrient rich plants and a rise in plant $\delta^{15} \mathrm{~N}$ values from spring into summer, i.e. across the period of antler growth, since plant $\delta^{15} \mathrm{~N}$ values have been shown to be positively correlated (albeit weakly) with temperature and negatively correlated with precipitation at a regional-scale ${ }^{[36,40]}$. This fits with temperature records from the years the antlers grew, which show increases on Rum from March to August (ca. 6 to $14^{\circ} \mathrm{C}$ ). It does not fit with those of rainfall, since patterning in precipitation does not follow a clear linear trend, typically decreasing from March to May, and then increasing again over the remaining summer and autumn months (June to Oct), but is also variable year to year (data from the Meterological Office weather station on Rum). A possible explanation combining both physiological and dietary parameters is that the change in dietary composition (specifically protein content) may alter the isotopic shifts associated with incorporation of the dietary isotopic signal, as has been hinted at from studies on ungulate ${ }^{[71]}$ but this has not been conclusively demonstrated. Regardless of the driving parameters, our results demonstrate that not all antler or parts thereof from an individual or a growth year are equivalent in carbon and nitrogen isotopic values, and isotopic signatures can vary within an antler.

Bone-antler comparison: 
A comparison of the maximum, minimum and mean antler $\delta^{13} \mathrm{C}_{\text {corr-ant }}$ and $\delta^{15} \mathrm{~N}$ values with the bone $\delta^{13} \mathrm{C}_{\text {corr-death, }} \delta^{13} \mathrm{C}_{\text {corr-5yr }}$ and $\delta^{15} \mathrm{~N}$ values from the same individuals shows that bone and antler carbon and nitrogen isotope signatures are not equivalent (Figure

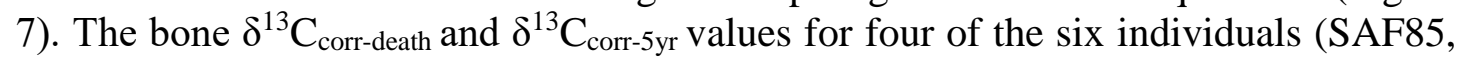
FAN85, TYS89 PIC90) are higher than all the antler $\delta^{13} \mathrm{C}_{\text {corr-ant values for the same }}$ individuals (15 antler), to a varying degree, but up to 1\%o higher in the case of FAN85. For INI85 the bone $\delta^{13} \mathrm{C}_{\text {corr-death }}$ and $\delta^{13} \mathrm{C}_{\text {corr-5yr }}$ values are within the range of antler $\delta^{13} \mathrm{C}_{\text {corr-ant }}$ values, overlapping with the range of three out of five antler. However, the bone $\delta^{13} \mathrm{C}_{\text {corr-death }}$ and $\delta^{13} \mathrm{C}_{\text {corr-5yr }}$ values are higher than mean antler $\delta^{13} \mathrm{C}_{\text {corr-ant }}$ values of four of the five antler analysed for this individual. For SUR86, only the bone $\delta^{13} \mathrm{C}_{\text {corr- }}$ 5yr value is within the range of antler $\delta^{13} \mathrm{C}_{\text {corr-ant }}$ values and this only overlaps with a single antler (that of 1995). To control for the "fossil fuel effect" we have used different correction factors for antler and bone (see start of discussion). That of antler is for year of growth, since we can know that for certain. But since bone is remodelled over time, it is not straightforward to assess the "year" of growth. The correction for year of death is not valid, but provides a terminus ante quem. More valid is likely to be a correction based on bone turnover rates, which are unknown, so we have approximated this by using a correction factor averaging the last five years of life. But the two corrections produce similar carbon isotopic values, suggesting that the choice of correction has minimal impact, and the true answer will be close in value to our two estimates. The offset between bone and antler carbon isotope values is therefore most probably not related to the fact that different correction factors are used for each.

The bone $\delta^{15} \mathrm{~N}$ values for three of the six individuals (SAF85, INI85, PIC90) are higher than all antler $\delta^{15} \mathrm{~N}$ values for the same individuals (11 antler). For the remaining three individuals (SUR86, FAN85, TYS89), the bone $\delta^{15} \mathrm{~N}$ are higher than the maximum $\delta^{15} \mathrm{~N}$ values for three of their antlers, but overlap with the range of $\delta^{15} \mathrm{~N}$ for two, one and two antlers respectively. The intra-antler patterns show that antler tip $\delta^{15} \mathrm{~N}$ are typically higher than antler coronet $\delta^{15} \mathrm{~N}$ and are therefore generally closer to that of bone and sometime equal to it (Figure 6).

With considerable variation within the antler isotope signatures, typical bone-antler offsets cannot be established for either $\delta^{13} \mathrm{C}$ or $\delta^{15} \mathrm{~N}$. Based on our results, bone and antler from the same individual can differ by up to $1.9 \%$ in $\delta^{13} \mathrm{C}$ values and by up to $1.2 \%$ in $\delta^{15} \mathrm{~N}$ values, with the $\delta^{13} \mathrm{C}$ and $\delta^{15} \mathrm{~N}$ values of bone being generally higher than those of antler. With increasing sampling distance from the coronet, antler $\delta^{15} \mathrm{~N}$ values increase, but we see no clear trend in antler $\delta^{13} \mathrm{C}$ values with length. The isotopic difference between bone and antler isotope signatures detected in this study could potentially be a result of several factors, which could differ between carbon and nitrogen. First, the bone-antler isotopic offset might reflect dietary differences resulting from differential timing and duration of tissue growth. Bone remodels year round so its isotope signatures average those of the year-round diet, potentially over several years, whereas antler grows over a 3 to 4 month period and therefore their isotope signatures are likely to be biased to the seasonal diet. For the timing of tissue growth to be the cause of the offset it would require seasonal changes in the dietary isotopic composition, either through changes in the isotopic signature of the plants or through changes in dietary selection. Plant $\delta^{13} \mathrm{C}$ and $\delta^{15} \mathrm{~N}$ values have been shown to vary seasonally due to seasonal climatic variations ${ }^{[33,64,71,73,74]}$, however we do not have vegetation isotopic data to show whether or not this occurs on the Isle of Rum. A study in eastern Scotland showed no significant correlation of plant carbon and nitrogen 
isotopic values with accumulated monthly precipitation, save for a weak positive relation for $\delta^{13} \mathrm{C}$ values of senescent leaves, whilst carbon and nitrogen isotopic values of green leaves, stems and senescent leaves were correlated with mean monthly temperature (negatively for $\delta^{15} \mathrm{~N}$, positively for $\delta^{13} \mathrm{C}$ ) with a high degree of variability

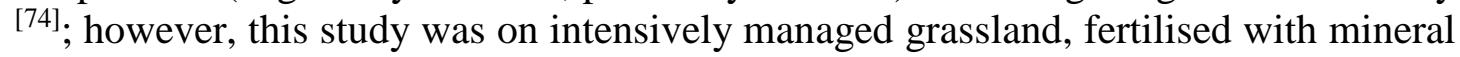
nitrogen throughout the growing season, so is not directly comparable to our study site. The deer are known to use different plant communities during different seasons. From November until April/May the deer generally prefer the long greens (dominated by Agrostis, Festuca and Carex), Juncus marsh, Molina grasslands and Calluna dominated communities. In mid-summer (June to August) they use the long greens and Juncus marsh communities, and in winter the deer prefer the Molina grasslands ${ }^{[55]}$. Again we do not have the vegetation isotopic data to say whether the isotope signatures of these plant communities are sufficiently different to result in seasonal changes in the dietary isotopic composition.

Another possibility is that the bone-antler isotopic offset may reflect seasonal changes in physiological demands. During the rut, from mid-September to mid-November, the stags rarely eat and nutritional stress results in a loss of condition. Furthermore the autumn rut is followed by the winter during which food is scarce and weather conditions are harsh which prolongs the period of nutritional stress. Nutritional stress has been show to result in elevated tissue $\delta^{15} \mathrm{~N}$ values as, in the absence of sufficient dietary protein, the body can catabolize its own tissue which is speculated to result in further nitrogen isotopic fractionation ${ }^{[27,75,76,77,78]}$. By contrast, periods of rapid growth, such as during antler formation discussed earlier, have been suggested to result in lower tissue $\delta^{15} \mathrm{~N}$ values $[26,65,66,67,68,69,70]$. The potential impact of seasonal changes in physiological demands on the deer $\delta^{13} \mathrm{C}$ values is however less clear as both positive and negative correlations have been seen between tissue $\delta^{13} \mathrm{C}$ values and nutritional stress, and the effects of growth on tissue $\delta^{13} \mathrm{C}$ values are currently poorly understood $^{[79,80,81]}$.

Finally the bone-antler isotopic offset may relate to the comparison of two distinct tissues (albeit of largely the same protein), with isotopic, physiological and temporal differences in the metabolic processes and pools for the synthesis of each tissue ${ }^{[82]}$. These differences might be expected to result in a degree of "biological noise" in the isotopic values measured within and between individuals, as well as potentially systematic differences. We argue that the differences observed between bone and antler are unlikely to be due solely to biological noise, because they are systematic, and are greater than might be expected from such noise. There are no isotopic data available to assess how representative the mandible is of other parts of the skeleton, but studies of bone turnover show that mandible bone turnover rates in dogs remain high into adulthood, in comparison to femoral turnover rates, in support of the idea that bone remodelling is linked to bone stress ${ }^{[83,84]}$, and thus that the mandible is likely to continue to remodel through life. Studies of turnover rates indicate that more rapidly turning over tissue pools have greater isotopic variability than slower ones, but there is minimal evidence from controlled dietary studies ${ }^{[55,86,87]}$. In bone, studies of adult humans shows some intra-bone isotopic variability, typically less than $0.3 \%$ o in carbon and nitrogen isotopic values, even when comparing faster-growing and slower-growing regions of the same bone ${ }^{[88,89]}$, whilst greater differences are seen in juveniles and in pathological material ${ }^{[89,90,91]}$ but none are from individuals on known diets. To our knowledge, intraindividual skeletal variability in carbon and nitrogen isotopic values has been measured 
in only one well-controlled study, showing intra-individual carbon and nitrogen isotopic variation of less than $0.5 \%$ in rabbit and mink ${ }^{[92]}$.

It is most probable that seasonal changes in dietary isotopic composition, physiological demands and metabolic processes all affect the bone-antler isotopic offset in carbon and nitrogen, as well as the patterns of isotopic change along the antler, in a complex fashion. For carbon, the antler-bone isotopic difference could result from seasonal changes in vegetation growth (lower plant $\delta^{13} \mathrm{C}$ values in summer, which is manifest in a lower antler $\delta^{13} \mathrm{C}$ values than in bone), but it is hard to reconcile the lack of seasonal variation in the antler $\delta^{13} \mathrm{C}$ values with the elevated bone $\delta^{13} \mathrm{C}$ values without a substantial step change in dietary isotope composition / physiological demands immediately impacting on tissue isotope signatures, whereas seasonal changes in both dietary isotope composition and physiological demands are more likely to be gradual. For nitrogen, we suggest that a combination of physiology (rapid tissue formation for antler, potential nutritional stress affecting bone isotopic values) and seasonal changes in plant nitrogen isotopic values result in lower antler nitrogen isotopic values that increase over the length, and tend towards but rarely reach the bone nitrogen isotopic values. Although we do not fully understand the mechanisms which control the offsets in both carbon and nitrogen, we can say for certain that bone and antler are not isotopically equivalent.

\section{Conclusions}

This study demonstrates that collagen $\delta^{13} \mathrm{C}$ and $\delta^{15} \mathrm{~N}$ values vary within antler, between antlers grown in different years by a single individual, and between antlers grown in a single year by different individuals. Samples from different points along the length of an antler may not give similar isotopic results, however samples taken from different branches at similar distances from the coronet appear to have similar $\delta^{13} \mathrm{C}$ and $\delta^{15} \mathrm{~N}$ values. We did not observe a consistent trend in $\delta^{13} \mathrm{C}$ values with distance along antler. By contrast a positive trend in $\delta^{15} \mathrm{~N}$ values with distance from coronet was observed in most antlers. The intra-antler isotopic variation likely tracks a combination of seasonal changes in the isotopic composition of diet and physiological parameters. An isotopic offset is observed between bone and antler $\delta^{13} \mathrm{C}$ and $\delta^{15} \mathrm{~N}$ values, with bone isotope values being higher than antler in most cases. This offset likely relates to the differential metabolic processes that occur during different tissue formation, as well as to physiological and dietary parameters. We can conclude that bone and antler collagen are not isotopically equivalent in carbon and nitrogen and are therefore not directly comparable in palaeodietary, palaeoclimate and palaeocological studies.

\section{Acknowledgements}

We are very grateful to: Catherine Kneale and James Rolfe for technical assistance with isotopic analysis; Scottish Natural Heritage and the Rum community for their support; Sean Morris, Alison Morris, Kelly Moyes and many other fieldworkers for collecting census data and samples; Daniel Nussey and Kelly Moyes for helpful discussions. The Rum red deer project has been funded by NERC grants to Tim Clutton-Brock, Loeske Kruuk and Josephine Pemberton who are thanked for access to long-term data. We thank the Newton Trust and the Royal Society (502008.K518/SLB) for financial support.

\section{Bibliography:}


1. P. A. Mellars. Reindeer specialization in the early Upper Palaeolithic: The evidence from south west France. J. Archaeol. Sci. 2004, 31, 613.

2. J. Clutton-Brock. Excavations at Grimes Graves Norfolk 1972-1976 Fascicule 1: Neolithic Antler Picks From Grimes Graves, Norfolk, and Durrington Walls, Wiltshire: A Biometrical Analysis. British Museum Press. 1984.

3. N. J. Sykes. Animal bones and animal parks. In: The Medieval Deer Park: new perspectives (Ed. R. Liddiard). Windgather Press, Macclesfield. 2007, pp. 4962.

4. J. S. Price, S. Allen, C. Faucheux, T. Althnaian, J. G. Mount. Deer antlers: a zoological curiosity or the key to understanding organ regeneration in mammals? J. Anat. 2005, 207, 603.

5. M. P. Richards, R. E. M. Hedges. Variations in bone collagen $\delta^{13} \mathrm{C}$ and $\delta^{15} \mathrm{~N}$ values of fauna from Northwest Europe over the last 40,000 years. Palaeogeogr. Palaeocl. Palaeoecol. 2003, 193, 261.

6. D. Drucker, H. Bocherens, A. Bridault, D. Billiou. Carbon and nitrogen isotopic composition of red deer (Cervus elaphus) collagen as a tool for tracking palaeoenvironmental change during the Late-glacial and early Holocene in the northern Jura (France). Palaeogeogr. Palaeocl. Palaeoecol. 2003, 195, 375.

7. D. Drucker, A. Bridault, K. A. Hobson, E. Szuma, H. Bocherens. Can carbon13 in large herbivores reflect the canopy effect in temperate and boreal ecosystems? Evidence from modern and ancient ungulates. Palaeogeogr. Palaeocl. Palaeoecol. 2008, 266, 69.

8. D. G. Drucker, A. Bridault, P. Iacumin, H. Bocherens. Bone stable isotopic signatures $\left({ }^{15} \mathrm{~N},{ }^{18} \mathrm{O}\right)$ as tracer of temperature variation in Late glacial and early Holocene: case study of red deer from Rochedane site in French Jura. Geol. J. 2009, 44, 593.

9. D. G. Drucker, C. J. Kind, E. Stephan. Chronological and ethological information on the early Holocene reindeer in NW Europe using radiocarbon and stable isotope analysis: case study from southern Germany. Quatern. Int. 2011, 245, 218.

10. D. G. Drucker, S. Madelaine, A. Morala. Les derniers rennes de Dordogne: nouvelles données chronologiques et environnementales par l'etude isotopique du collagène $\left({ }^{13} \mathrm{C},{ }^{14} \mathrm{C}\right.$ et $\left.{ }^{15} \mathrm{~N}\right)$. Paleo 2011, 22, 85.

11. D. G. Drucker, A. Bridault, C. Cupillard, A. Hujic, H. Bocherens. Evolution of habitat and environment of red deer (Cervus elaphus) during the Late-glacial and early Holocene in eastern France (French Jura and the western Alps) using multi-isotope analysis $\left(\delta^{13} \mathrm{C}, \delta^{15} \mathrm{~N}, \delta^{18} \mathrm{O}, \delta^{34} \mathrm{~S}\right)$ of archaeological remains. Quat. Int. 2012, 245, 268.

12. D. J. Halley K. Kaji, M. Minagawa. Variation in stable isotope ratios of carbon and nitrogen in Hokkaido sika deer Cervus nippon during 1990-2000: possible causes and implications for management. Wildlife Biology 2006, 12, 211.

13. R. Barberena, C. Méndez, F. Mena, O. Reyes. Endangered species, archaeology, and stable isotopes: huemul (Hippocamelus bisulcus) isotopic ecology in central-western Patagonia (South America). J. Archaeol. Sci. 2011, $38,2313$.

14. N. J. Sykes, K. H. Baker, R. F. Carden, T. F. G. Higham, A. R. Hoelzel, R. E. Stevens. New evidence for the establishment and management of the European fallow deer (Dama dama dama) in Roman Britain. J. Archaeol. Sci. 2011, 38, 156. 
15. R. E. Stevens, A. M. Lister, R. E. M. Hedges. Predicting trophic level, diet, and palaeoecology from stable isotope analysis: a comparative study of five red deer populations. Oecologia 2006,149, 12.

16. R. E. Stevens, R. Jacobi, M. Street, M. Germonpré, N. J. Conard, S. C. Münzel, R. E. M. Hedges. Nitrogen isotope analyses of reindeer (Rangifer tarandus), 45,000 BP to 9,000 BP: Palaeoenvironmental reconstructions. Palaeogeogr. Palaeocl. Palaeoecol. 2008, 262, 32.

17. R. E. Stevens, X. L. H. Buxán, A. B. Marín-Arroyo, M. González-Morales, and L. G. Straus. Investigating palaeonvironment change across the PleistoceneHolocene transition at El Mirón (Cantabria, Spain) through carbon and nitrogen isotope analysis of red deer. Palaeogeogr. Palaeocl. Palaeoecol. 2014, 414, 46.

18. R. Madgwick, N. Sykes, H. Miller, R. Symmons, J. Morris, A. Lamb. Fallow deer (Dama dama dama) management in Roman South-East Britain. Archaeol. Anthropol. Sci. 2013, 5, 111.

19. M. Gąsiorowski, H. Hercman, B, Ridush, K. Stefaniak. Environment and climate of the Crimean Mountains during the Late Pleistocene inferred from stable isotope analysis of red deer (Cervus elaphus) bones from the Emine-BairKhosar Cave. Quat. Int. 2014, 326, 243.

20. H. Bocherens, D. Billiou, A Tresset. Approche biogéochimique $\left({ }^{13} \mathrm{C},{ }^{15} \mathrm{~N}\right) \mathrm{de}$ l'exploitation de l'environnement par les humains, in: Louviers "La Villette" (Eure): un site néolithique moyen en zone humide (Ed. F. Giligny). Documents Archéologies de l'Ouest, Rennes, 2005, pp. 265-269.

21. X. I. Tian, C. Zhu, Z. B. Sun, T. Shui, Y. P. Huang, R. K. Flad, Y. M. Li. Carbon and nitrogen stable isotope analyses of mammal bone fossils from the Zhongba site in the Three Gorges Reservoir region of the Yangtze River, China. Chinese Science Bulletin 2011, 56, 169.

22. D. A. Schoeller. Isotopic fractionation: why aren't we what we eat. J. Archaeol. Sci. 1999, 26, 667.

23. S. C. Polischuk, K. A. Hobson, M. A. Ramsay. Use of stable-carbon and nitrogen isotopes to assess weaning and fasting in female polar bears and their cubs. Can. J. Zool. 2001, 79, 499.

24. M. Sponheimer, T. Robinson, L. Ayliffe, B. Roeder, J. Hammer, A. West, B. Passey, T. Cerling, D. Dearing, J. Ehleringer. Nitrogen isotopes mammalian herbivores: hair $\delta^{15} \mathrm{~N}$ values from a controlled-feeding study. Int. J. Osteoarchaeol. 2003, 13, 80.

25. M. Sponheimer, T. F. Robinson, B. L. Roeder, B. H. Passey, L. K. Ayliffe, T. E. Cerling, M. D. Dearing, J. R. Ehleringer. An experimental study of nitrogen flux in llamas: is ${ }^{14} \mathrm{~N}$ preferentially excreted? J. Archaeol. Sci. 2003, 30, 1649.

26. B. T. Fuller, J. L. Fuller, N. E. Sage, D. A. Harris, T. C. O’Connell, R. E. M. Hedges. Nitrogen balance and delta N-15: why you're not what you eat during pregnancy. Rapid Commun. Mass Spectrom. 2004, 18, 2889.

27. B. T. Fuller, J. L. Fuller, N. E. Sage, D. A. Harris, T. C. O'Connell, R. E. M. Hedges. Nitrogen balance and delta15N: why you're not what you eat during nutritional stress. Rapid Commun. Mass Spectrom. 2005, 19, 2497.

28. C. T. Robbins, L. A. Felicetti, M. Sponheimer. The effect of dietary protein quality on nitrogen isotope discrimination in mammals and birds. Oecologia 2005, 144, 534.

29. K. A. Hatch. The use and application of stable isotope analysis to the study of starvation, fasting, and nutritional stress in animals. In: Comparative physiology 
offasting, starvation, and food limitation. (Ed. M. D. McCue) Springer. Berlin, Heidelberg 2012, pp 337-364.

30. T. Deschner, B. T. Fuller, V. M. Oelze, C. Boesch, J. J. Hublin, R. Mundry, M. P. Richards, S. Ortmann, G. Hohmann. Identification of energy consumption and nutritional stress by isotopic and elemental analysis of urine in bonobos (Pan paniscus). Rapid Commun. Mass Spectrom. 2012, 26, 69.

31. C. Martínez del Rio, S. A. Carleton. How fast and how faithful -the dynamics of isotopic incorporation into animal tissues. J. Mammal. 2012. 93, 353-359.

32. M. H. O'Leary. Carbon isotope fractionation in plants. Phytochemistry 1981, 20, 553.

33. T. H. E. Heaton. Spatial, species and temporal variations in the $\mathrm{C}-13 / \mathrm{C}-12$ ratios of C-3 plants: implications for palaeodiet studies. J. Archaeol. Sci. 1999 26, 63.

34. R. D. Evans. Physiological mechanisms influencing plant nitrogen isotope composition. Trends Plant Sci. 2001, 6, 121.

35. D. Robinson. $\delta^{15} \mathrm{~N}$ as an integrator of the nitrogen cycle. Trends Ecol. Evol. 2001, 16, 153.

36. R. Amundson, A. T. Austin, E. A. G. Schuur, K. Yoo, V. Matzek, C. Kendall, A. Uebersax, D. Brenner, W. T. Baisden. Global patterns of the isotopic composition of soil and plant nitrogen. Global Biogeochem. Cycles 2003, 17, 1031.

37. J. M. Craine, A.J. Elmore, M. P. Aidar, M. Bustamante, T. E. Dawson, E. A. Hobbie, A. Kahmen, M. C. Mack, K. K. McLauchlan, A. Michelsen, G. B. Nardoto, L. H. Pardo, J. Peñuelas, P. B. Reich, E. A. Schuur, W. D. Stock, P. H. Templer, R. A. Virginia, J. M. Welker, I. J. Wright. Global patterns of foliar nitrogen isotopes and their relationships with climate, mycorrhizal fungi, foliar nutrient concentrations, and nitrogen availability. New Phytologist 2009, 183, 980.

38. M. J. Kohn. Carbon isotope compositions of terrestrial C3 plants as indicators of (paleo)ecology and (paleo)climate. PNAS. 2010, 107, 19691.

39. L. A. Cernusak, N. Ubierna, K. Winter, J. A. M. Holtum, J. D. Marshall, G. D. Farquhar. Environmental and physiological determinants of carbon isotope discrimination in terrestrial plants, New Phytologist 2013, 200, 950.

40. E. A. Hobbie, P, Högberg. Nitrogen isotopes linke mycorrhizal fungi and plants to nitrogen dynamics. New Phytologist. 2012, 196, 367.

41. M. J. DeNiro, S. Epstein. Influence of diet on the distribution of carbon isotopes in animals. Geochim. Cosmochim. Acta. 1978, 42, 495.

42. M. J. DeNiro, S. Epstein. Influence of diet on the distribution of nitrogen isotopes in animals. Geochim. Cosmochim. Acta. 1981, 45, 341.

43. M. Sponheimer, T. Robinson, L. Ayliffe, B. Passey, B. Roeder, L. Shipley, E. Lopez, T. Cerling, D. Dearing, J. Ehleringer. An experimental study of carbonisotope fractionation between diet, hair, and feces of mammalian herbivores. Can. J. Zool. 2003, 81, 871.

44. L. D. Tegland, T.F. Robinson, M. Sponheimer, B.L. Roeder, L. Ayliffe. Turnover of liver and muscle tissue determined by dietary stable isotope incorporation. Faseb Journal. 2003, 17, A700.

45. L. K. Ayliffe, T. E. Cerling, T. Robinson, A. G. West, M. Sponheimer, B. H. Passey, J. Hammer, B. Roeder, M. D. Dearing, J. R. Ehleringer, Turnover of carbon isotopes in tail hair and breath $\mathrm{CO}_{2}$ of horses fed an isotopically varied diet. Oecologia 2004, 139, 11. 
46. B. H. Passey, T. F. Robinson, L. K. Ayliffe, T. E. Cerling, M. Sponheimer, M. D. Dearing, B. L. Roeder, J. R. Ehleringer, Carbon isotope fractionation between diet, breath $\mathrm{CO}_{2}$, and bioapatite in different mammals. J. Archaeol. Sci. 2005, 32, 1459.

47. S. Caut, E. Angulo, F. Courchamp. Variation in discrimination factors (Delta(15)N and Delta(13)C): the effect of diet isotopic values and applications for diet reconstruction. J. Appl. Ecol. 2009, 46, 443.

48. J. Vaughan. The Physiology of Bone. 3rd ed. Oxford Univerisity Press, Oxford 1981.

49. R. E. M. Hedges, J. G. Clement, D. L. Thomas, T. C O'Connell. Collagen turnover in the adult femoral mid-shaft: Modeled from anthropogenic radiocarbon tracer measurements. Am. J. Phys. Anthropol. 2007, 133, 808.

50. S. H. Ambrose, L. Norr, in Prehistoric human bone - Archaeology at the molecular level. (Eds J.B. Lambert, G. Grupe), Springer Verlag, Berlin. 1993, pp.1-37.

51. L. L. Tieszen, T. Fagre, in Prehistoric human bone - Archaeology at the molecular level. (Eds. J.B. Lambert, G. Grupe), Springer Verlag, Berlin. 1993, pp.121-155.

52. S. Krauss, W. Wagermaier, J. A. Estevez, J. D. Currey, P. Fratzl. Tubular frameworks guiding orderly bone formation in the antler of the red deer (Cervus elaphus). J. Struct. Biol. 2011, 175, 457.

53. V. J. Tzalkin. Data for a study on the horns of the true deer (Cervus elaphus L.). Zoologichesky Zhurnal 1945, 24, 224.

54. J. S. Price, S. Allen. Exploring the mechanisms regulating regeneration of deer antlers. Philos. Trans. R. Soc. B. 2004, 359, 809.

55. T. C. Clutton-Brock, F. E. Guinness, S. D. Albon. Red Deer: Behaviour and Ecology of Two Sexes. University of Chicago Press, Chicago. 1982.

56. T. Coulson, S. Albon, F. Guinness, J. Pemberton, T.H. Clutton-Brock. Population substructure, local density, and calf winter survival in red deer (Cervus elaphus). Ecology 1997, 78, 852.

57. D. H. Nussey, B. Metherell, K. Moyes, A. Donald, F.E. Guinness, T. H. CluttonBrock. Tooth wear in a wild red deer population: Effects of habitat quality, but no consequences for late life reproduction. J. Anim. Ecol. 2007, 76, 402.

58. R. Longin. New method of collagen extraction for radiocarbon dating. Nature 1971, 230, 241.

59. T. C. O'Connell, R. E. M. Hedges, M. A. Healey, A. H. R. W. Simpson. Isotopic comparison of hair, nail and bone: Modern analyses. J. Archaeol. Sci. 2001, 28, 1247.

60. J. Hoefs. Stable isotope geochemistry. Springer, Heidelberg. 1997.

61. R. J. Francey, C. E. Allison, D. M. Etheridge, C. M. Trudinger, I. G. Enting, M. Leuenberger, R. L. Langenfelds, E. Michel, L. P. Steele. A 1000 year high precision record of $\delta^{13} \mathrm{C}$ in atmospheric $\mathrm{CO}_{2}$, Tellus, Ser. B. 1999, 51, 170.

62. R. F. Keeling, S. C. Piper, A. F. Bollenbacher, S. J. Walker. Monthly atmospheric ${ }^{13} \mathrm{C} /{ }^{12} \mathrm{C}$ isotopic ratios for 11 SIO stations. In Trends: $A$ Compendium of Data on Global Change. Carbon Dioxide Information Analysis Center, Oak Ridge National Laboratory, U.S. Department of Energy, Oak Ridge, Tenn., U.S.A. 2010.

63. E. S. Long, R. A. Sweitzer, D. R. Diefenbach, M. Ben-David. Controlling for anthropogenically induced atmospheric variation in stable carbon isotope studies. Oecologia 2005, 146, 148. 
64. A. F. Diefendorf, K.E. Mueller, S. L. Wing, P. L. Koch, K. H. Freeman. Global patterns in leaf ${ }^{13} \mathrm{C}$ discrimination and implications for studies of past and future climate. Proc. Natl. Acad. Sci. 2010, 107, 5738.

65. H. Sick, N. Roos, E. Saggau, K. Haas, V. Meyn, B. Walch, N. Trugo. Amino acid utilization and isotope discrimination of amino nitrogen in nitrogen metabolism of rat liver in vivo. Z. Ernährungswiss 1997, 36, 340.

66. J. Gaye-Siessegger, U. Focken, H. Abel, K. Becker. Feeding level and diet quality influence trophic shift of $\mathrm{C}$ and $\mathrm{N}$ isotopes in Nile tilapia (Oreochromis niloticus (L.)). Isot. Environ. Health Stud. 2003, 39, 125.

67. J. Gaye-Siessegger, U. Focken, H. Abel, K. Becker. Individual protein balance strongly influences $\delta^{15} \mathrm{~N}$ and $\delta^{13} \mathrm{C}$ values in Nile tilapia, Oreochromis niloticus. Naturwissenschaften. 2004, 91, 90.

68. C. N. Trueman, R. A. R. McGill, P. H. Guyard. The effect of growth rate on tissue-diet isotopic spacing in rapidly growing animals: an experimental study with Atlantic salmon (Salmo salar). Rapid Commun. Mass Spectrom. 2005, 19, 3239.

69. A. L. Water-Rist, M. A. Katzenberg. The effect of growth on stable nitrogen isotope ratios in subadult bone collagen. Int. J. Osteoarchaeol. 2010, 20, 172.

70. C. Martinez del Rio, B. O. Wolf, in Physiological and ecological adaptations to feeding in vertebrates (Ed. M. Stark) NH: Science Publishers, Enfield. 2005, pp. 141-174.

71. M Sponheimer, TF Robinson, BL Roeder, BH Passey, LK Ayliffe, TE Cerling, MD Dearing, JR Ehleringer. An experimental study of nitrogen flux in llamas: is ${ }^{14} \mathrm{~N}$ preferentially excreted? J. Archaeol. Sci. 2003, 30, 12.

72. L.D. Coletta, G. B. Nardoto, S. R. Latansio-Aidar, H. R. D. Rocha. Isotopic view of vegetation and carbon and nitrogen cycles in a cerrado ecosystem, southeastern Brazil. Sci. Agric. 2009, 66, 467.

73. J. Codron, D. Codron, J. A. Lee-Thorp, M. Sponheimer, W. J. Bond, D. de Ruiter, R. Grant. Taxonomic, anatomical, and spatio-temporal variations in the stable carbon and nitrogen isotopic compositions of plants from an African savanna. J. Archaeol. Sci. 2005, 32, 1757.

74. L. Wang, J. K. Schjørring. Seasonal variation in nitrogen pools and ${ }^{15} \mathrm{~N} /{ }^{13} \mathrm{C}$ natural abundances in different tissues of grassland plants. Biogeosci. 2012, 9 , 1583.

75. K. A. Hobson, R. T. Alisauskas, R. G. Clark. Stable-nitrogen isotope enrichment in avian tissues due to fasting and nutritional stress: implications for isotopic analyses of diet. The Condor 1993, 95, 388.

76. C. C. Voigt, F. Matt. Nitrogen stress causes unpredictable enrichments in ${ }^{15} \mathrm{~N}$ in two nectar feeding bat species. J. Exp. Biol. 2004, 207, 1741.

77. Y. Cherel, K.A. Hobson, F. Bailleul, R. Groscolas. Nutrition, physiology, and stable isotopes: new information from fasting and molting penguins. Ecology 2005, 86, 2881.

78. A. M. Mekota, G. Grupe, S. Ufer, U. Cuntz. Serial analysis of stable nitrogen and carbon isotopes in hair: monitoring starvation and recovery phases of patients suffering from anorexia nervosa. Rapid Commun. Mass Spectrom. 2006, 20, 1604.

79. C. T. Williams, C. L. Buck, J. Sears, A. S. Kitaysky. Effects of nutritional restriction on nitrogen and carbon stable isotopes in growing seabirds. Oecologia 2007, 153, 11. 
80. M. D. McCue, E. D. Pollock. Stable isotopes may provide evidence for starvation in reptiles. Rapid Commun. Mass Spectrom. 2008, 22, 2307.

81. K. L. Robertson, N. E. Rowland, J. Krigbaum. Effects of caloric restriction on nitrogen and carbon stable isotope ratios in adult rat bone. Rapid Commun. Mass Spectrom. 2014, 28, 2065.

82. N. Poupin, F. Mariotti, J-F. Huneau, D. Hermier, H. Fouillet. Natural isotopic signatures of variations in body nitrogen fluxes: A compartmental model analysis. Plos Computational Biology, 2014, 10.

83. S.S. Huja, S.A. Fernandez, K.J. Hill, Y. Li. Remodeling dynamics in the alveolar process in skeletally mature dogs. Anat. Rec. A Discov. Mol. Cell Evol. Biol. 2006, 288, 1243.

84. S.S. Huja, F.M. Beck. Remodeling dynamics in the alveolar process in skeletally mature dogs. Anat. Rec. (Hoboken), 2007, 291, 1.

85. F. Dalerum, A. Angerbjorn. Resolving temporal variation in vertebrate diets using naturally occurring stable isotopes. Oecologia, 2005, 144, 647.

86. S.M. Thomas, T.W. Crowther. Predicting rates of isotopic turnover across the animal kingdom: a synthesis of existing data, J. Anim. Ecol. 2015, 84, 861.

87. M.J. Vander Zanden, M.K. Clayton, E.K. Moody, C.T. Solomon, B.C. Weidel. Stable isotope turnover and half-life in animal tissues: A literature synthesis, Plos One, 2015, 10.

88. R.E.M. Hedges, A. Saville, T.C. O'Connell. Characterizing the diet of individuals at the Neolithic chambered tomb of Hazleton North, Gloucestershire, England, using stable isotopic analysis, Archaeometry, 2008, 50, 114.

89. M.A. Katzenberg, N.C. Lovell, Stable isotope variation in pathological bone, Int. J. Osteoarchaeol. 1999, 9, 316.

90. M.L.S. Jorkov, J. Heinemeier, N. Lynnerup. The petrous bone - A new sampling site for identifying early dietary patterns in stable isotopic studies, Am. J. Phys. Anthropol. 2009, 138, 199.

91. A.L. Waters-Rist, V.I. Bazaliiskii, A.W. Weber, M.A. Katzenberg. Infant and child diet in Neolithic hunter-fisher-gatherers from Cis-Baikal, Siberia: Intralong bone stable nitrogen and carbon isotope ratios, Am. J. Phys. Anthropol. 2011, 146, 225.

92. M.J. DeNiro, M.J Schoeninger. Stable carbon and nitrogen isotope ratios of bone collagen: variations within individuals, between sexes, and within populations raised on monotonous diets, J. Archaeol. Sci. 1983, 10, 199. 
Figure Captions:

Figure 1. Location of Isle of Rum and study area in which deer lived.

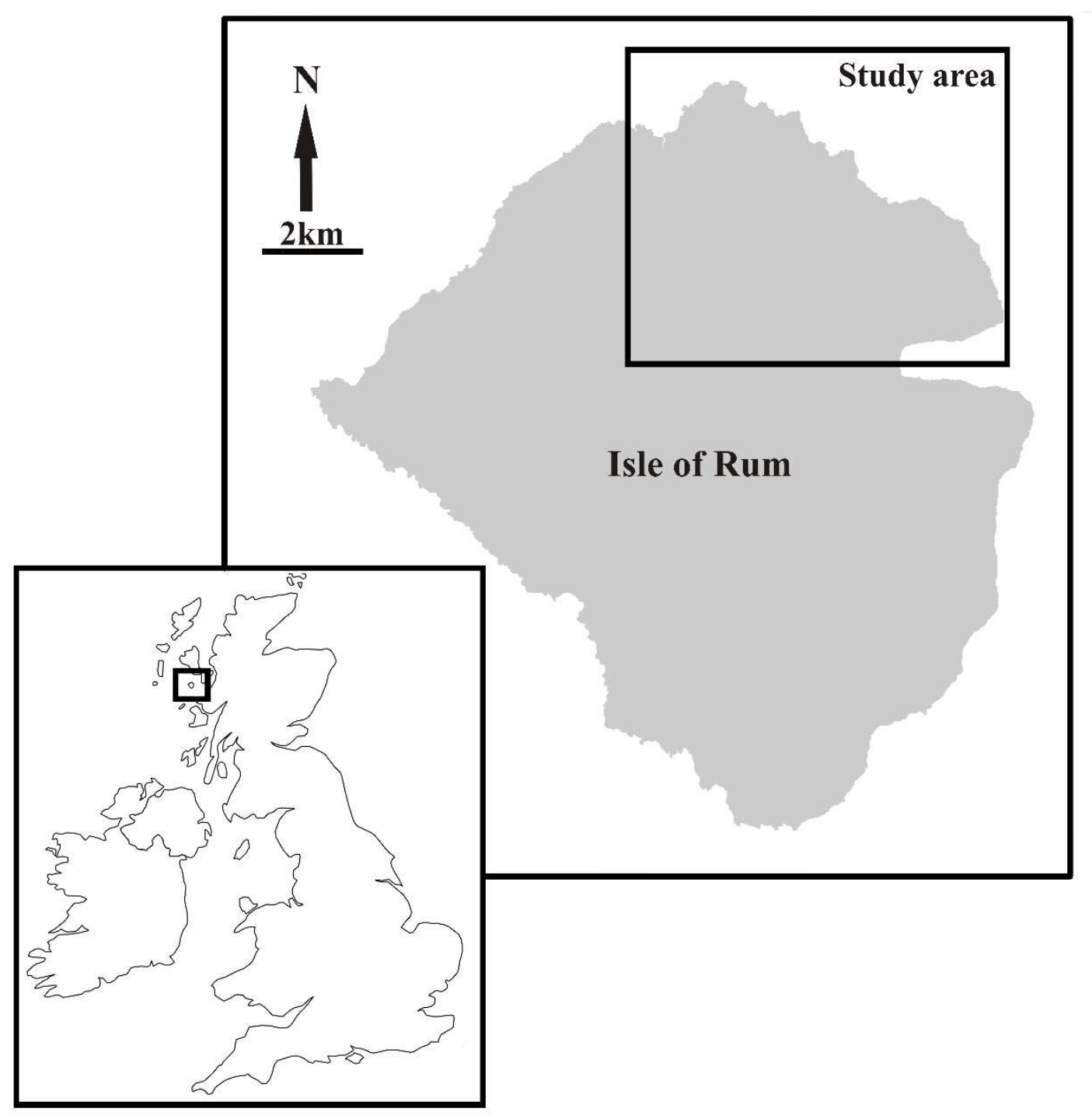


Figure 2: Antler anatomy (Holes show where antler has been sampled).

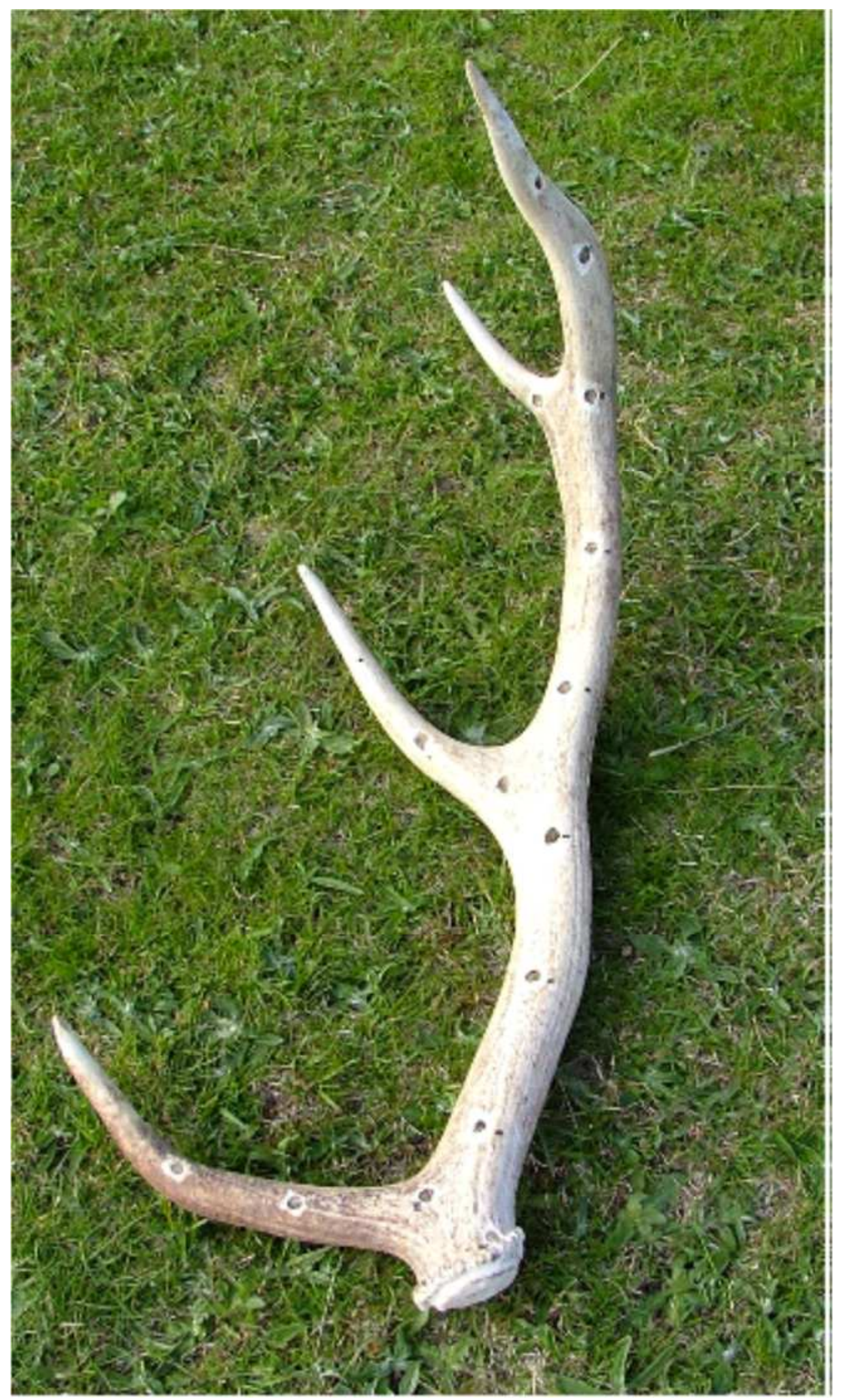


Figure 3: All antler and bone collagen carbon and nitrogen isotope values plotted by stag. Carbon isotopic values $\delta^{13} \mathrm{C}_{\text {corr-ant }}$ corrected according to Long et al ${ }^{[63]}$ based on year of growth for antler and year of death for bone.

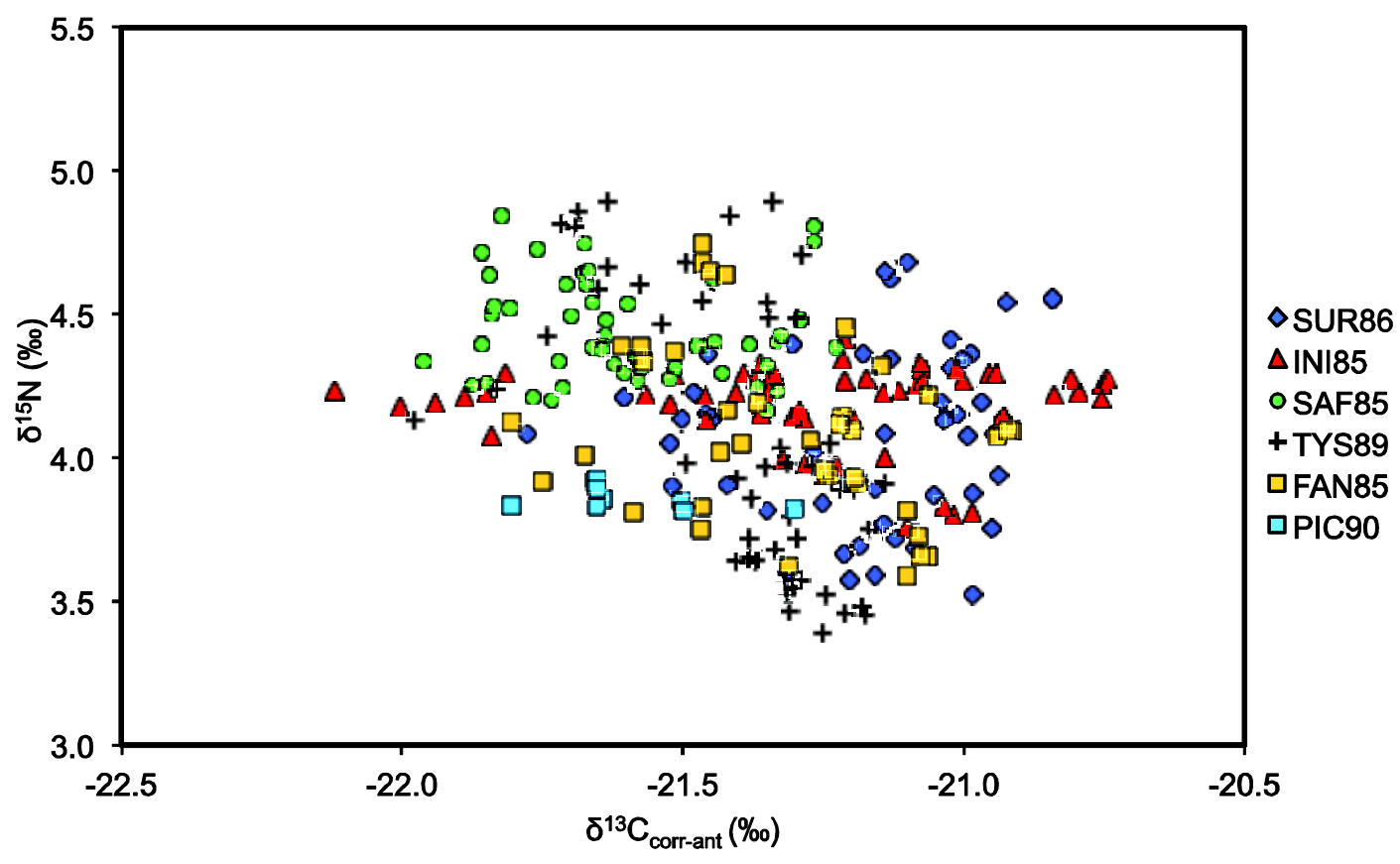


Figure 4: Intra-antler collagen collagen carbon and nitrogen isotope values plotted by year of antler shedding. Carbon isotopic values $\delta^{13} \mathrm{C}_{\text {corr-ant }}$ corrected according to Long et $\mathrm{al}^{[62]}$ based on year of antler growth. Measurement error indicated by bar in corner of graph. X-axis indicates distance from coronet (formed first). 

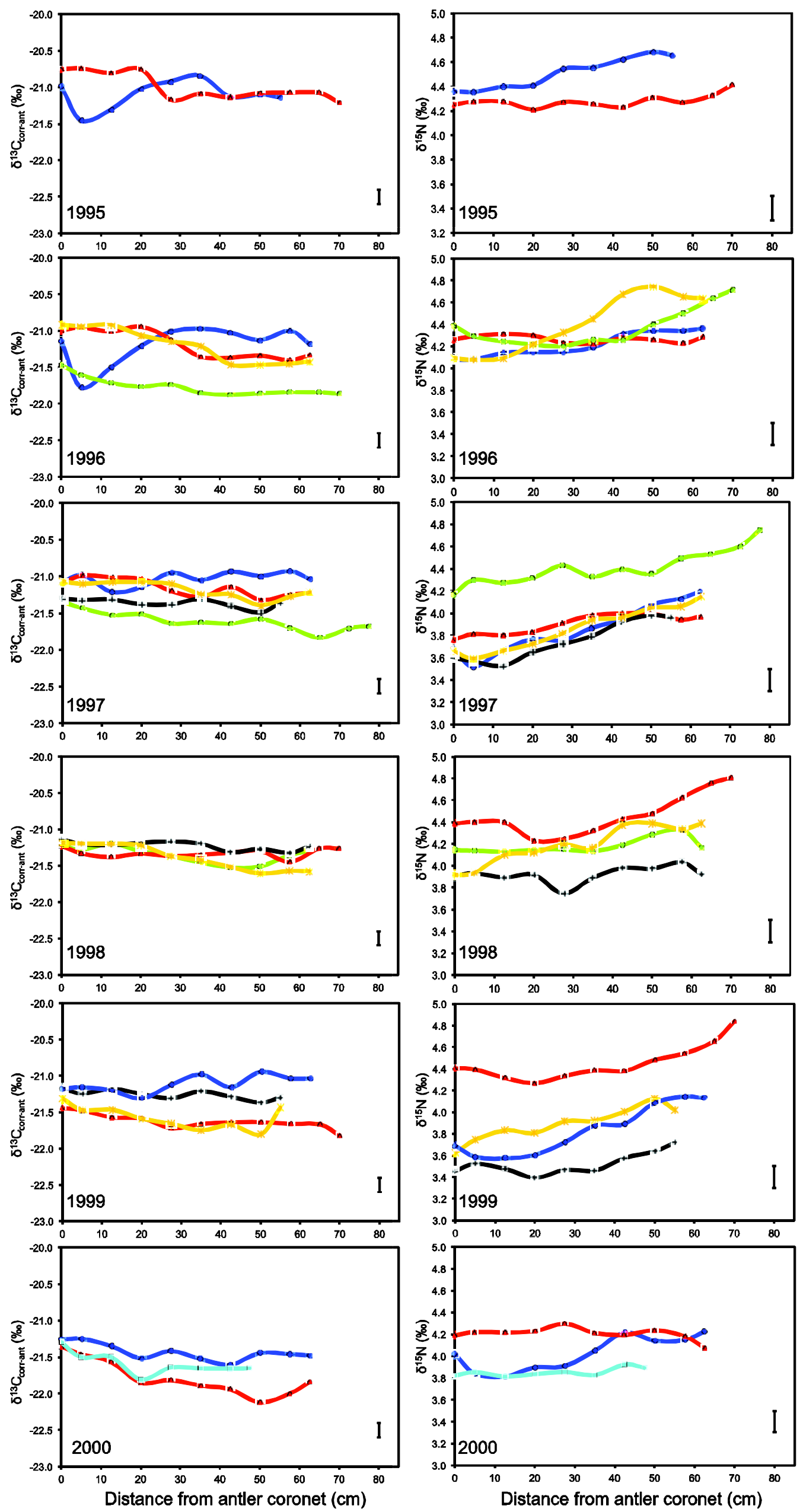
Figure 5: Antler carbon $\left(\delta^{13} \mathrm{C}_{\text {corr-ant }}\right)$ and nitrogen isotopic values plotted by year of antler shedding. Maximum, minimum and range of collagen $\delta^{13} \mathrm{C}_{\text {corr-ant }}$ and $\delta^{15} \mathrm{~N}$ values indicated by vertical bar, crosses indicate mean values.
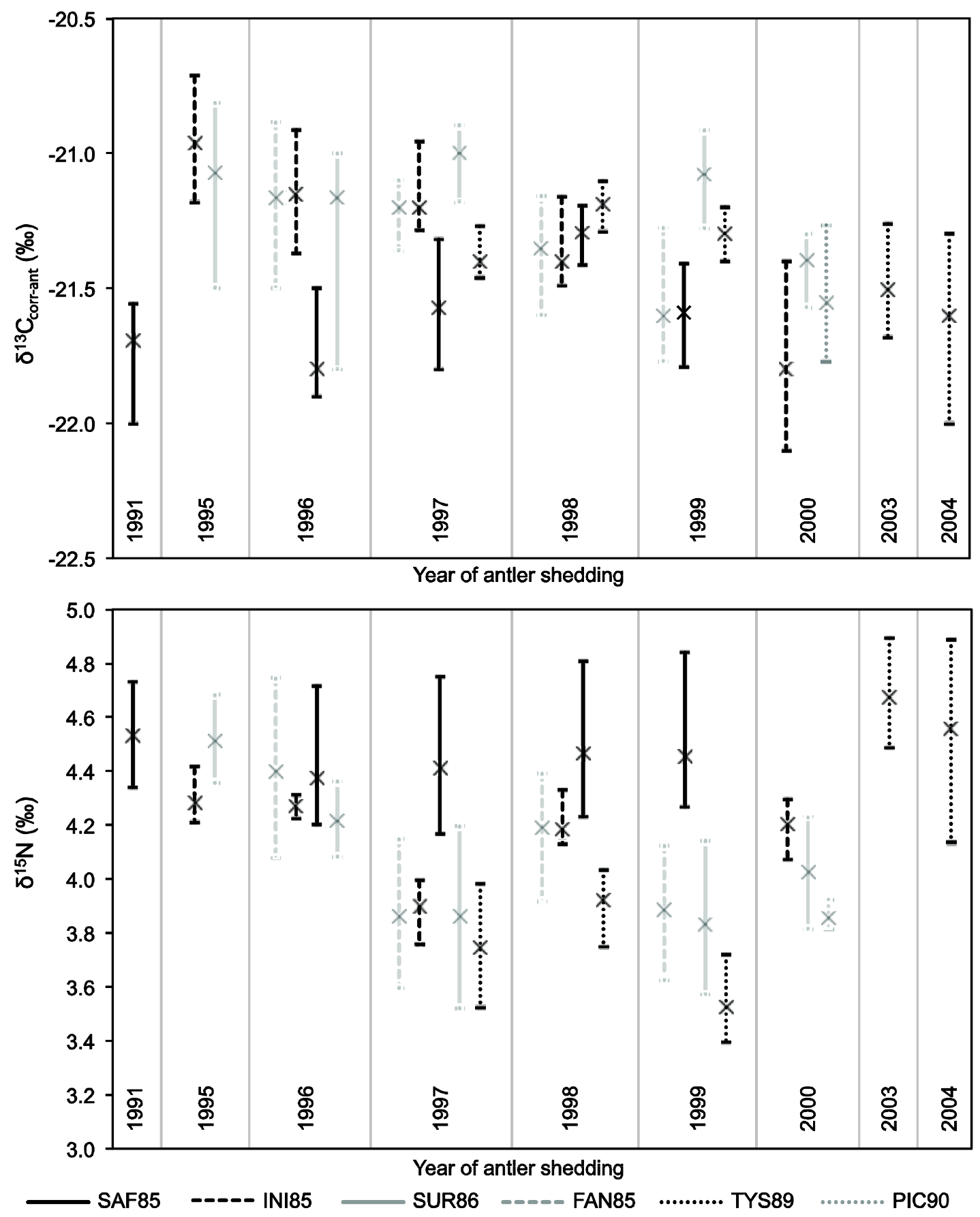
Figure 6: Intra-antler collagen carbon $\left(\delta^{13} \mathrm{C}_{\text {corr-ant }}\right)$ and nitrogen isotopic values plotted by stag. Cross indicates bone $\delta^{13} \mathrm{C}_{\text {corr-death }}$ and bone $\delta^{15} \mathrm{~N}$ values. Measurement error indicated by bar in corner of graph. $\mathrm{X}$-axis indicates distance from coronet (formed first). 

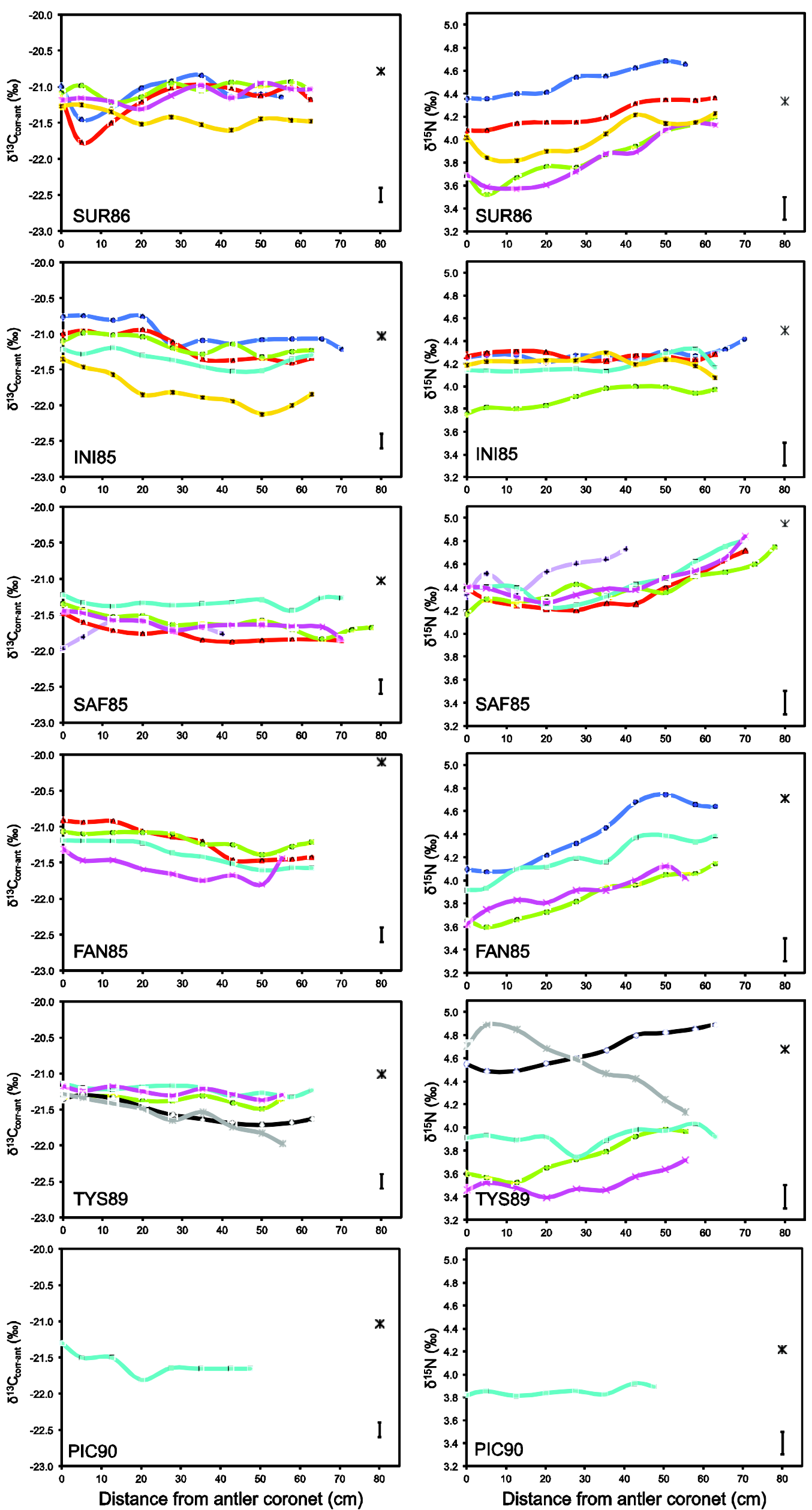

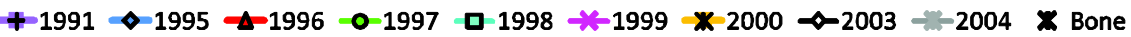


Figure 7: Bone and antler collagen carbon $\left(\delta^{13} \mathrm{C}_{\text {corr-ant }}\right)$ and nitrogen isotopic values plotted by antler and by stag. Maximum, minimum and range of antler collagen $\delta^{13} \mathrm{C}_{\text {corr-ant }}$ and $\delta^{15} \mathrm{~N}$ values indicated by vertical bar, crosses indicate mean values.

Blue horizontal lines indicate bone $\delta^{13} \mathrm{C}_{\text {corr-death values, green horizontal lines indicate }}$

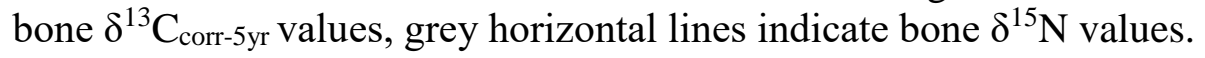

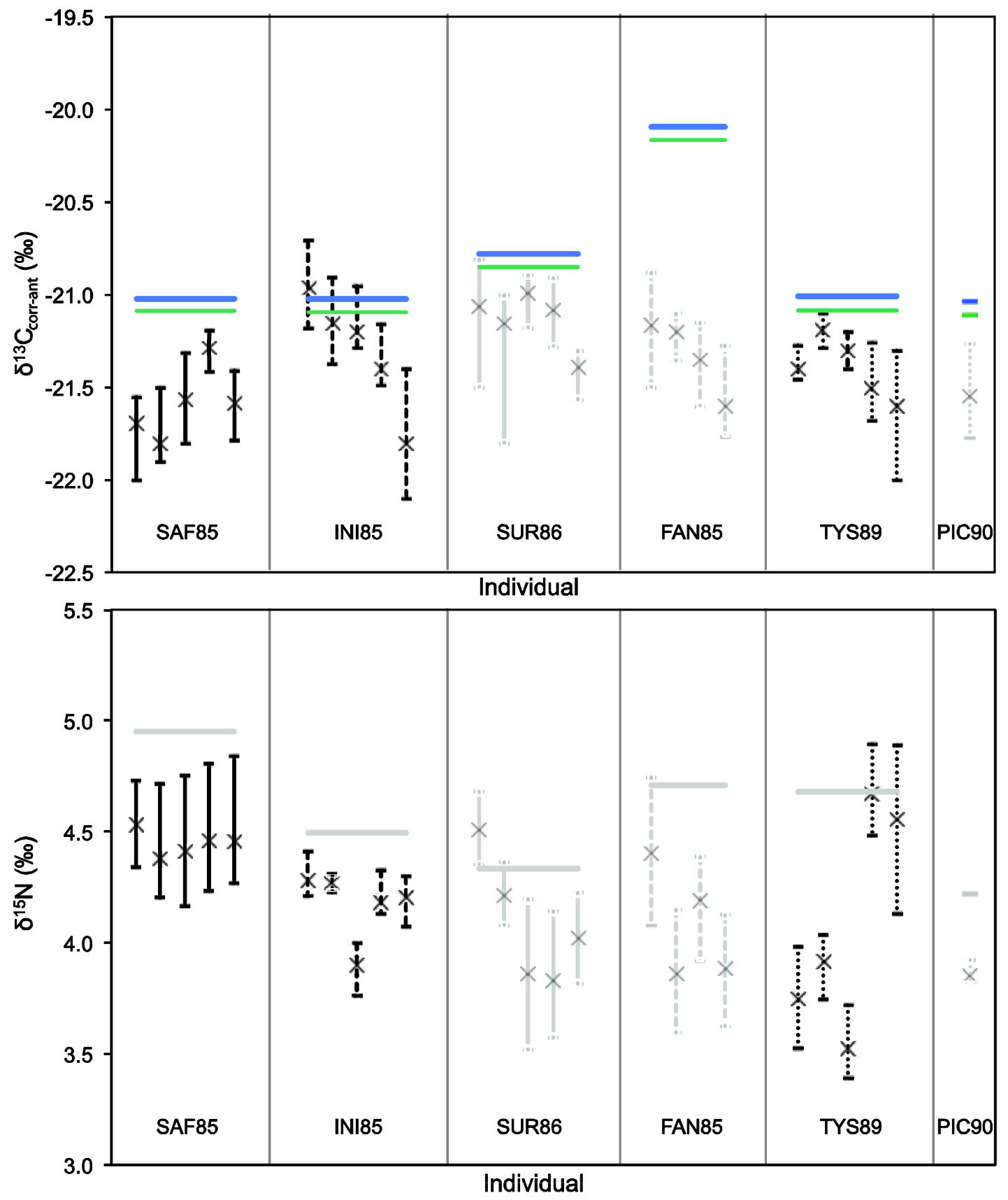


Figure 8: Intra-antler collagen carbon $\left(\delta^{13} \mathrm{C}_{\text {corr-ant }}\right)$ and nitrogen isotopic for different branches of antler plotted for two stags, TYS89 and INI85. Antler collagen $\delta^{13} \mathrm{C}_{\text {corr-ant }}$ and $\delta^{15} \mathrm{~N}$ values shown as red, green and blue lines. Cross indicates bone collagen $\delta^{13} \mathrm{C}_{\text {corr-death }}$ and $\delta^{15} \mathrm{~N}$ values. Measurement error indicated by bar in corner of graph.
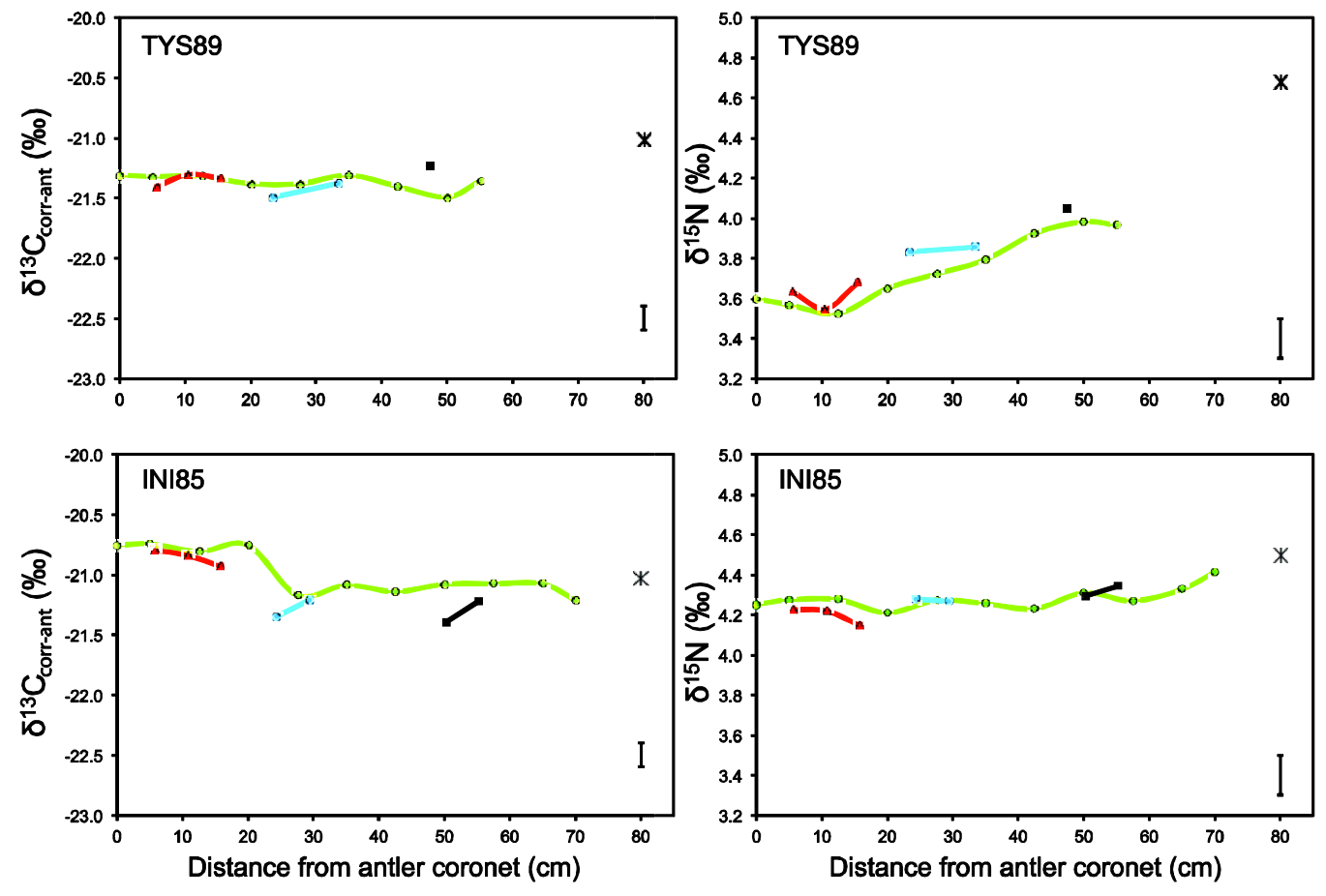

$\diamond$ Main beam $\circ$ Trey

$\triangle$ Brow

Point $*$ Bone 